\title{
CEO Compensation System in Large Canadian Financial Institutions*
}

\author{
Yusuf Mohammed Nulla ${ }^{1}$, Dimitris Nikolaou Koumparoulis ${ }^{2}$
}

\begin{abstract}
:
This study investigated the CEO Compensation system of the Canadian Financial Institutions. It attested the relationship between the CEO Compensation, the Firm Size, the Firm Performance, and the CEO Power, in the TSX/S\&P index companies from the period 2005 to the period 2010. The totalled of the eighteen largest Canadian financial companies were selected through the random sampling method from the TSX/S\&P index. The research question for this study was: is there a relationship between the CEO Cash Compensation, the Firm Size, the Firm Performance, and the CEO Power? To answer this question, six statistical models were created and accordingly six attestations were performed. It was found that, there was a relationship between the CEO Salary, the Firm Size, the Firm Performance, and the CEO Power; there was a relationship between the CEO Bonus and the CEO Power; and there was a relationship between the CEO Total Compensation and the Firm Size and Firm Performance. However, it was found that there was no relationship between the CEO Bonus, the Firm Size, and the Firm Performance. In addition, it was found that there was no relationship between the CEO Total Compensation and the CEO Power. The correlation between the CEO Cash Salary, the Firm Size, and the Firm Performance was positively good to strong ratios; the correlation between the CEO Salary and the CEO Power was negatively weak ratio; and the correlation between the CEO Bonus, the Firm Size, the Firm Performance, and the CEO Power was positively weak.
\end{abstract}

Key Words:

CEO Compensation, Firm Performance, Firm Size, CCEO Power, Canadian Financial Institutions, Accounting Performance

JEL Classification: G0, G19, G29

\footnotetext{
* Acknowledgement: The authors would like to express their gratitude to the Journal's Assistant Editor Mr. Georgios Dafnos for his invaluable contribution to this paper's publication.

${ }^{1}$ D.Phil. \& Ph.D. Student, UGSM Monarch Business School

${ }^{2}$ Professor of Economics and Management, Universidad Azteca, Mexico, e-mail:dnkoumparoulis@hotmail.gr
} 


\section{Introduction}

The purpose of this research is to understand in-depth the Canadian financial institutions CEO Cash Compensation system. In addition, over the past decade in Canada, the Canadian public had raised concerns over the huge bonuses declared to the CEOs by their board of directors. The failure to understand the determinants of the CEO cash compensation by the public had leaded to blaming the CEOs of rent grabbing; misused of its power towards board; and its monopolization of the compensation system. Thus, these ever growing concerns bring to the foreground conclusion the need to further study in depth, at least one of the major industries in the Canada, the financial institutions, the primary relationship and the resulting dynamics between the CEO Cash Compensation, the Firm Size, the Firm Performance, and the CEO Power.

The CEOs and the other executives would like to eliminate the risk exposure in their compensation packages by decoupling their pay from performance and linking it to a more stable factor, the Firm Size. This strategy indeed deviates from obtaining the optimum results from the principal-agent contracting. The past studies had found a strong relationship between the CEO Compensation and the Firm Size but the correlations results were ranged from the nil to the strong positive, among the large company's studies. The variables used in the past studies as a proxy for the Firm Size were the Total Sales, the Total Number of Employees, or the Total Assets. Therefore, the Firm Size needs to be studied with the CEO Cash Compensation on an extensive basis such as: using both the Total Sales and the Total Number of Employees.

The most researched topic in the executive compensation is between the CEO Compensation and the Firm Performance. Although the executive compensation and the firm performance had been the subject of debate amongst the academic, there was little consensus on the precise nature of the relationship as such, further researched in greater detail need to be conducted to understand in the finer terms the true extent of the relationship between them. As such, this research had unprecedentedly used eight variables to attest with the CEO Cash Compensation, that is, the Return on Assets (ROA), the Return on Equity (ROE), the Earnings per Share (EPS), the Cash Flow per Share (CFPS), the Net Profit Margin (NPM), the Book Value per Common Shares Outstanding (BVCSO), and the Market Value per Common Shares Outstanding (MVCSO).

The relationship between the CEO compensation and the CEO power was not attested extensively in the past, especially in Canada. In fact, only few credible researched papers were available for to study. That is, the CEO power only has been the subject of the recent focus among the researchers, primarily due to the effect of the researchers failed to find the strong relationship between the CEO 
Compensation, the Firm Size, and the Firm Performance. The variables used in the past studies as a proxy for the CEO Power such as, the CEO Age; the CEO Tenure; and the CEO Tenure, were found to have the weak to the negligible relationship with the CEO Compensation. In addition, the third party data collection, the lower quality of the sampling population focus such as at the industry level, and the use of different statistical methods, all had leaded to the divergency in the results. Therefore, the CEO Power needs to be studied with the CEO Cash Compensation on an extensive basis such as using, the CEO Age, the CEO Shares Outstanding, the CEO Share Value, the CEO Tenure, the CEO Turnover, the Management 5 percent ownership, and the Individuals/Institutions 5 percent ownership.

\section{Literature review}

\subsection{CEO Cash Compensation and Firm Size}

Gomez-Mejia and Barkema (1998) defined the relationship between CEO Cash Compensation and Firm Size as: A positive relationship between the CEO compensation and the firm performance would be consistent with the agency theory, the dominant paradigm in this stream of research. The CEOs cash incentives have a strong relationship with the firm size as the CEOs in larger companies make higher income than the CEOs in the smaller companies. This is supported by Finkelstein and Hambrick (1996) that the firm size is related to the level of executive compensation. According to Tosi and Gomez-Mejia (1994) the measurement of the firm size was the composite score of the standardized values of reported the total sales and the number of employees. Shafer (1998) showed that the pay sensitivity (measured as the dollar change in CEO wealth per dollar change in firm value) falls with the square root of the firm size. That is, the CEO incentives are 10 times higher for a $\$ 10$ billion firm than for a $\$ 100$ million firm.

From the famous meta-analysis conducted by Tosi, Werner, Katz, and Gomez-Mejia (2000) they found that the estimated correlation between the CEO pay and the aggregate firm size factor is .643, signifying that the firm size accounts for over $40 \%$ of the variance in CEO pay. Similarly, the adjusted composite correlation between the change in the CEO pay and the change in the Firm Size is .225, accounting for about $5 \%$ of the variance in changes in the CEO pay. In addition, they found that the CEOs can exert more influence over the Firm Size than the CEO Performance, and therefore, they would prefer to use the firm size as the criterion for the compensation purposes. Firstly, this is supported by Simmons, \& Wright (1990) that the CEO pay increases considerably following a major acquisition even when the firm performance suffers. Secondly, Kostiuk (1990) argued that the greater the size may be used to legitimize the higher CEO pays by appealing to rationalizations to justify a size premium. Rationalizations may include: the greater organizational complexity; and more CEO human capital required to run the business (Agarwal, 1981). Thirdly, executives are risk averse. They can reduce or eliminate risk 
exposure in their compensation package by decoupling their pay from performance and linking it to a more stable factor, the firm size (Dyl, 1988; and McEachern, 1975). In addition, according to Gomez-Mejia (1994) a host of structural factors and the pragmatic problems make it difficult for the corporations to effectively control executives, leading to the compensation packages that are more closely tied to the firm size than the performance. According to Sigler (2011) the firm size appears to be the most significant factor in determining the level of the total CEO compensation. His examination was based on the 280 firms listed on the New York Stock Exchange from 2006 to 2009.

There was substantial evidence that the firm size was a major determinant of the CEO pay Fox (1983). Finkelstein and Hambrick (1989) believed that the bigger firms tend to pay more because the CEO oversees substantial resources, rather than because of their number of hierarchical pay levels. This theory was explained in other form by Fox (1983) that the CEOs are paid more in the larger firms primarily due to its leadership demand and more hierarchical layers exist in the larger firms. However, the results have varied from nil to strongly positive associations between the CEO compensation and the larger firms (Finkelstein and Hambrick, 1989).

Gomez-Mejia, Tosi, and Hinkin (1987) believed that the firm size was a less risky basis for setting executives' pay than performance, which was subject to many uncontrollable forces outside the managerial sphere of influence. Similarly, McEachern (1975) argued that the CEOs in management-controlled firms will prefer to avoid the risk of tying pay to the performance, therefore, the firm size, which was likely to vary less than performance, will most affect pay. This was supported by Hambrick and Finkelstein (1995) and Gomez-Mejia, Tosi, and Hinkin (1987) that the firm size was related to the total pay in the management-controlled firms but not the owner-controlled firms suggesting that the managerial control was a moderator of the pay-size relationship. In the owner-controlled firms, the large share of compensation should be contingent on the firm performance than was base salary (Gomez-Mezia, Tosi, and Hinkin, 1987). Murphy (1985) showed that the holding the value of a firm constant, a firm whose sales grow by 10 percent will increase the salary and bonus of its CEO by between 2 percent and 3 percent. These findings suggested that the size-pay relation is causal. It also suggests that CEOs can increase their pay by increasing the firm-size, even when the increase in size reduces the firm's market value. Prasad (1974) believed that executive salaries appear to be far more closely correlated with the scale of operations of the firm than its profitability. He also believed that the executive compensation was primarily a reward for the past sales performance and was not necessarily an incentive for future sales efforts.

Tosi et al. (2000) believed that the most of the studies conducted by scholars found that the executive pay as a control mechanism are remarkably inconsistent not only 
with the theory but with each other. This is supported by studies conducted by Belkaoui and Picur (1993), David, Koachhar, and Levitas (1998), and Gray and Cannella (1997) that the correlations between the firm size and the CEO pay are as low as .107, .110, and .170, while studies conducted by Boyd (1994), and Finkelstein and Boyd (1998) reported correlations of .62, .50, and .42.

\subsection{CEO Cash Compensation and Firm Performance linkage}

The CEO cash compensation is generally believed to be weakly related to the firm performance, according to a majority of studies conducted in the United States and the UK. It is believed that the CEO power and weaker governance plays an important role in the weak relationship between the CEO cash compensation and the firm performance. Henderson and Fredrickson (1996) stated that while the CEO total pay may be unrelated to performance, it is related to the organizational complexity that they manage. Likewise, other similar studies conducted by Murphy (1985), Jensen and Murphy (1990), Joskow and Rose (1994) and Thalassinos, Havlíček and Berezkinova (2012) for SMEs, supported this nature of the relationship.

Jensen and Murphy (1990) argued that incentive alignment as an explanatory agency construct for the CEO pay is weakly supported at best. That is, objective provisions of principal-agent contract cannot be comprehensive enough to effectively create a strong direct CEO pay and performance relationship. They found that the pay performance sensitivity for the executives is approximately $\$ 3.25$ per $\$ 1000$ change in the shareholder wealth, the "small for an occupation in which the incentive pay is expected to play an important role". This is supported by legendary work of Tosi, Werner, Katz, and Gomez-Mejia (2000) on pay studies in the form of the metaanalysis that the overall ratio of the change in the CEO pay and change in the financial performance is 0.203 , an accounting for about $4 \%$ of the variance. The estimated true correlation between the CEO pay and the Return on Equity is .212 . And the estimated true correlation between the CEO pay and the Total Assets is 0.117. Thus, these other financial measures account for less than the $2 \%$ of the variance in the CEO pay levels. This weak relationship is explained by Borman and Motowidlo (1993) and Rosen (1990) who stated that the archival performance data focuses only on a small portion of the CEO's job performance requirements and therefore it is difficult to form an overall conclusion.

According to Jensen and Murphy (1990) it is possible that the CEO bonuses are strongly tied to an unexamined or unobservable measure of the performance. If the bonuses depend on the performance measures observable only to the board of directors and are highly variable, they could provide a significant incentives. One way to detect the existence of such "phantom" performance measures is to examine the magnitude of year-to-year fluctuations in the CEO compensation. The large swings in the CEO pay from year to year were consistent with the existence of an 
overlooked but important performance measure: small annual changes in the CEO pay suggested that the CEO pay was essentially unrelated to all the relevant performance measures. Furthermore, they argued that although bonuses represent $50 \%$ of the CEO salary, such bonuses were awarded in ways that were not highly sensitive to performance as measured by changes in the market value of the equity, the accounting earnings, or the sales. In addition, they found that, that while more of the variation in the CEO pay could be explained by the changes in the accounting profits than the stock market value, however, the pay-performance sensitivity remains insignificant.

Jensen and Murphy (1990) found in their studies that the CEO received an average pay increase of $\$ 31,700$ in years when the shareholders earned the zero return, and received on average an additional $1.35 \phi$ per $\$ 1,000$ increase in the shareholder's wealth. These estimates are comparable to those of Murphy (1985 and 1986), Coughlan and Schmidt (1985) and Gibbons and Murphy (1990) who found payperformance elasticity of approximately 0.1 - the salaries and the bonuses increased by about one percent for every ten percent rise in the value of the firm. Additionally, they stated that the average pay increase for the CEO whose shareholders gain $\$ 400$ million was $\$ 37,300$, compared to an average pay increase of $\$ 26,500$ for the CEO whose shareholders lose $\$ 400$ million. Their Forbes study was based on the Executive Compensation Surveys covered from the period 1974 to1986. Jensen and Murphy (1990) provided one explanation for the small pay-performance sensitivity was that, the boards have fairly good information regarding the managerial activity and therefore the weight on output was small relative to the weight on input.

On the other hand, Jensen and Zimmerman (1985) argued that the evidence was inconsistent with the view that executive compensation is unrelated to the firm performance and that the executive compensation plans enrich managers at the expense of shareholders. This argument was supported by Mehran (1995) reported that the CEO pay structure was positively related to same-year performance. In addition, Gibbons and Murphy (1990) also found in their studies that the CEO salaries and the bonuses were positively and significantly related to the firm performance as measured by the rate of return on common stock. That is, CEO pay changes by about $1.6 \%$ for each $10 \%$ return on the common stock. In addition, they found that the CEO cash compensation was positively related to the firm performance and negatively related to the industry performance, ceteris paribus. Similarly, Antle and Smith (1986) found no relation between the salary and the bonus and the industry returns. Blanchard, Lopez-de-Silanes and Shleifer (1994) and Bertrand and Mullainathan (2001) argued that there was an evidence that CEO cash compensation increases when firm profits rise for reasons that clearly have nothing to do with managers' efforts. 
Murphy (1985) and Jensen and Murphy (1990) found a significant relationship between the level of pay (measured by changes in executive wealth) and the performance (measured by changes in firm value). At the same time, Jensen and Murphy (1990) argued that the failure to include the cash performance measure in the pay-performance studies may thus create the impression that the management compensation was unresponsive to the corporate performance. Similarly, Iyengar (2000) found that on the average, the level of the CEO cash compensation was positively related to the firms' level of the operating cash flows. On the other hand, Carpenter and Sanders (2002) argued that the CEO's total pay may be unrelated to the performance, but it may relate to the organizational complexity that they manage. This argument was supported by Jensen and Murphy (1989) as he provided additional hypothesis in the form of political forces factor in the contracting process which implicitly regulate executive compensation by constraining the type of the contracts that can be written between the management and the shareholders. These political forces, operating in both the political sector and within organizations, appear to be important but were difficult to document because they operate in informal and indirect ways. The public disapproval of high rewards seems to have truncated the upper tail of the earnings distribution of the corporate executives. The equilibrium in the managerial labour market then prohibits the large penalties for the poor performance and as a result the dependence of pay on performance was decreased. Their findings that, the pay-performance relation; the raw variability of the pay changes; and the inflation-adjusted pay levels, have declined substantially since the1930s, was consistent with such implicit regulation.

Mehran (1995) found that the companies in which the CEO compensation was relatively sensitive to the firm performance tend to produce the higher returns for the shareholders than the companies in which the relationship between the CEO pay and the performance was weak. Lambert and Larcker (1987) and Sloan (1993) found in their empirical studies that there was a positive relation between the CEO compensation and the stock returns. Jensen and Murphy (1990) believed that the cash compensation should be structured to provide big rewards for the outstanding performance and the meaningful penalties for the poor performance. Also, they believed that weak link between the CEO cash compensation and the corporate performance would be less troubling if the CEOs owned a large percentage of corporate equity.

According to McEachern (1975), Allen (1981), Amould (1985), Gomez-Mejia, Tosi, and Hinkin (1987), Dyl (1988), Gomez-Mejia and Tosi (1989), Kroll, Simmons, and Wright (1989), the relationship between the executive pay and the performance may be stronger in the owner-controlled than in the management-controlled firms. Werner and Tosi (1995) showed that the managers in widely held firms are paid more than the managers in the closely held firms through the higher salaries, the higher bonuses, and the higher long-term incentives. Dyl (1988) argued that that 
there is a downside hedge in the pay of CEOs in management-controlled firms, given that it is more strongly related to the firm size, not the performance. He also believed that, the owner-controlled firms will seek to transfer some of the risks borne to the managers, and this should be reflected in their compensation policies (Antle and Smith, 1986).

\subsection{CEO Cash Compensation and CEO Power}

It is believed that the CEO in the larger firms tend to own less stock and have less compensation-based incentives than the CEOs in the smaller firms. This is supported by Jensen and Murphy (1985) by stating that our all-inclusive estimate of the payperformance sensitivity for the CEOs in the firms in the top half of our sample (ranked by market value) is $\$ 1.85$ per $\$ 1,000$, compared to $\$ 8.05$ per $\$ 1,000$ for the CEOs in the firms in the bottom half of our sample. In addition, they (1990) argued that as a percentage of the total corporate value, the CEO share ownership had never been very high. The median CEO of one of the nation's 250 largest public companies own shares worth just over $\$ 2.4$ million - again, less than $0.07 \%$ of the company's market value. Also, 9 out of 10 CEO own less than $1 \%$ of their company's stock, while less than 1 in 20 owns more than $5 \%$ of the company's outstanding shares. Jensen and Murphy (1990) found in their study that the most powerful link between the shareholder wealth and the executive wealth was direct ownership of the shares by the CEO. They found, on average, the CEOs receive about $50 \%$ of their base pay in the form of the bonuses. They argued that most experts assessed the CEO stock ownership in terms of the dollar value of the CEO's holdings or the value of his shares as a percentage of his annual cash compensation. However, they also argued that neither of these measures was relevant in the CEO incentive determination. They believed that the percentage of the company's outstanding shares of the CEO ownership influences the CEO's pay. However, their statistical analysis found no correlation between the CEO stock ownership and payfor-performance sensitivity in cash compensation. That is, the board of directors ignore the CEO stock ownership when structuring incentive plans. This is supported by Cyert, Kang, and Kumar (2002) study who found a negative correlation between the equity ownership of the largest shareholder and the amount of the CEO compensation: doubling the percentage ownership of the outside shareholder reduces the non-salary compensation by $12-14$ percent. This was supported to the great extent by Murphy and Jensen (1990) who found in their study that there was a small and insignificant positive coefficient of the ownership-interaction variable exist, which implied that the relation between compensation and performance was independent of an executive's stock holdings. The result that the pay-performance relation was not affected by stock ownership seems inconsistent with the agency theory since the optimal compensation contracts that provide incentives for managers to create shareholder wealth will not be independent of their shareholdings. Their study findings were based on the sampling of the 73 manufacturing firms for the 15 years period. Cyert, Kang, and Kumar (2002) also 
argued that the CEO pay is negatively related to the share ownership of the board's compensation committee; and doubling compensation committee ownership reduces non-salary compensation by 4-5 percent. In addition, many other studies also failed to find any relationship between the firm value and the executives' equity stakes (e.g., Agrawal and Knoeber 1996; Himmelberg et al. 1999; Demsetz and Villalonga 2001; Zampeta 2012), primarily due to the equity holdings were the decision of the managers and the boards, none of these correlations can be interpreted as causal. However, these findings were challenged by Mehran (1995) who found a positive relationship between the percentage of total compensation in cash (salary and bonus) and the percentage of shares held by managers. This was supported by Jensen and Murphy (1990) found in their study that changes in both the CEO's pay-related wealth and the value of his stock holdings were positively and statistically related to the changes in the shareholder's wealth, and the CEO turnover probabilities were negatively and significantly related to changes in shareholder wealth. Ungson and Steers (1984) believed that in the firms where the CEO had large shareholdings, long tenure, control of the top management team, or other means, the CEO can largely shape his or her pay. Similarly, Finkelstein and Hambrick (1988) believed that the relative power of the CEO may affect the height of the hurdles that are set to qualify for the contingent pay. In addition, they also believed that the executives who own the significant portions of their firms are likely to control not only the operating decisions but the board decisions as well. As such, the executives would be in a position to essentially set their own compensation. In addition, they believed that the stronger the family's position in the firm, the stronger will be the executive's position, despite the family shareholders may not be as active as the independent directors might be. They also found that the CEO compensation and shareholdings are related in an inverted- $U$ manner, with the compensation highest in situations of moderate the CEO ownership. That is, the point of inflection happened when the CEO shareholdings reached about the 9 percent. Up to that point, increases in the CEO ownership seemed to bring increased salaries, due to increase in the CEO Power and the CEO Tenure for the first 18 years, and beyond that ownership level, the salaries dropped, due to tax preference of incurring the capital gains over the current income.

Jensen and Murphy (1989) found that the executive inside-stock ownership can provide incentives, but these holdings are not generally controlled by the corporate board, and the majority of the top executives have the small personal equity ownership. Bertrand and Mullainathan (2000) found that the CEOs in the firms that lack a 5 percent (or larger) external shareholder tend to receive more luck-based pay -pay associated with the profit increases that are entirely generated by the external factors rather than by managers' efforts. They also found that in the firms lacking large external shareholders, the cash compensation of CEOs is reduced less when their option-based compensation is increased. 
Murphy (1986) argued that the CEO tenure had shown to influence the CEO performance pay in prior research. The increased CEO tenure may promote a principal's trust of an agent and the assumption that actions will be taken in the principal's interest. Sigler (2011) argued that the CEO tenure appears to be one of the significant variables in determining the level of the CEO compensation. His examination was based on the 280 firms listed on the New York Stock Exchange for a period from 2006 to 2009 .

Finkelstein and Hambrick (1989) believed that the CEO tenure was thought to have a positive link with the compensation, with pay steadily increasing as the CEO gains and solidifies the power over-time. However, in their findings such a pattern was not observed for any of the measures of the CEO compensation. Since a monotonic relationship was not found between the CEO tenure and the CEO pay, the existence of a curvilinear association was investigated. In addition, the average tenure of the CEOs was significantly lower in the externally-controlled firms (2.96 years) than the management-controlled firms (5.92 years). Thus, they believed that the boards of the externally-controlled firms may not need to pay from the profitability because the CEO tenure was dependent on the owner's satisfaction with the CEO performance. For the total pay, this finding was relatively strong with the inflation adjusted pay starting to decline at about 18 years of tenure. According to them there were two possible explanations for this curvilinear pattern. The first was that the power accrues for a while and then diminishes due to the CEO's reduced mobility in the managerial labor market, or due to his evolution into a figurehead with one or two younger high priced executives who carry the actual weight of the CEO's job. The second possibility was that executive reach a point where they prefer other forms of the compensation over the current cash. This could occur because of the changes in the family and the financial circumstances, or due to a switch to reliance on the stock appreciation and dividends, as the CEO's shareholdings increase over-time. This supposition was supported when the two subsamples were examined $(\mathrm{p}<0.01)$ greater shareholdings than a short-tenure low-pay group. Hence, it was not that longer-tenured CEOs are paid less, but rather that the pay mix shifts from the cash to the stock earnings over-time, supporting the notion that personal circumstances influence pay. They also argued that the longer the CEO's tenure, the more the board will consist of his or her own, often sympathetic appointees. In addition, the management-controlled firms where the CEOs were relatively powerful, CEO tenure was likely to be important to pay determinants. Despite their detailed findings their study was inconclusive as they failed to derive strong expected correlations among the variables due to the small sample-sized sampling which had affected the results not being representative of the larger population. However, Pfeffer (1981) supported Finkelstein and Hambrick (1989) findings and believed that the creation of a personal mystique which may induce unquestioned deference or loyalty can be expected to occur when the CEO power becomes institutionalized in the 
organization. A second source of power that is expected to affect compensation is the executive's shareholdings in the firm.

Deckop (1988) argued that the CEO's age had little effect on the CEO compensation. However, Finkelstein and Hambrick (1998) found an inverted Ushaped relationship between the CEO age and the CEO cash compensation. The cash compensation increased with an age up to a point at 59 years, beyond which real cash earnings decreased. They also believed that this pattern of the earnings over-time is in line with the CEO's need for cash, which tends to drop off as he or she gets older due to no major expenditures to incur such as house and child-rearing expenses

\section{Research methodology}

This research had adopted the quantitative research method as it is the method to be used for the historical data collection and the descriptive studies. The longitudinal study approach had been selected under the quantitative research methodology to study the corporate financial records from 2005 to 2010. The stratified sampling method had been selected to obtain the total sampling population of the eighteen companies for this research from the TSX/S\&P index.

For the statistical tests, the CEO Cash Compensation was assigned as the dependent variable; the Firm Size was assigned as the control variable and the independent variable; and the CEO Performance and the CEO Power had been assigned as independent variables. Each sub-variables of the CEO Cash Compensation had been used separately to attest with all the sub-independent variables of the Firm Size, the Firm Performance, and the CEO Power. The total of the six models were created and accordingly attest each of them to address the research question.

The survey method had been adopted as it is the most appropriate approach to collect the historical data. The historical data of the sampled companies had been obtained from the TMX Group Inc. and the CDS Inc. The Inferential statistics-based methodology, which is very instrumental to this quantitative research, had been used to obtain statistical results. The 95 percent confidence level will be assumed for all the research attestations. 


\section{Data Findings}

\subsection{CEO Compensation System}

Table 1: Regression Analysis (ANOVA)

\begin{tabular}{|l|l|l|l|}
\hline & Salary & Bonus & Total Compensation \\
\hline \multirow{4}{*}{ Firm Size } & $\mathrm{F}_{(2,105)}=47.34$ & $\mathrm{~F}_{(2,105)}=0.025$ & $\mathrm{~F}_{(2,236)}=25.510$ \\
& $\mathrm{p}=.000$ & $\mathrm{p}=.976$ & $\mathrm{p}=.000$ \\
& $\mathrm{R}^{2}=0.474$ & $\mathrm{R}^{2}=0.000$ & $\mathrm{R}^{2}=0.128$ \\
\hline \multirow{5}{*}{ Firm Performance } & $\mathrm{F}_{(8,93)}=14.031$ & $\mathrm{~F}_{(8,93)}=1.247$ & $\mathrm{~F}_{(8,93)}=1.96$ \\
& $\mathrm{p}^{=.000}$ & $\mathrm{p}=.281$ & $\mathrm{p}=.006$ \\
& $\mathrm{R}^{2}=0.547$ & $\mathrm{R}^{2}=0.311$ & $\mathrm{R}^{2}=0.144$ \\
\hline \multirow{3}{*}{ CEO Power } & $\mathrm{F}_{(7,100)}=12.71$ & $\mathrm{~F}_{(7,100)}=2.334$ & $\mathrm{~F}_{(7,100)}=1.545$ \\
& $\mathrm{p}^{2}=.000$ & $\mathrm{p}=.03$ & $\mathrm{p}^{2}=.161$ \\
& $\mathrm{R}^{2}=0.471$ & $\mathrm{R}^{2}=0.14$ & $\mathrm{R}^{2}=0.098$ \\
\hline
\end{tabular}

Table 1 results were based on the linear regression testing. It showed that there was a relationship between the CEO Salary, the Firm Size, and the CEO Power. It showed that there is a relationship between the CEO Bonus and the CEO Power; however, there was no relationships found between the CEO Bonus, the Firm Size, and the Firm Performance. In addition, it showed that there is relationship between the CEO Total Compensation and the Firm Size yet there was no relationship found between the CEO Total Compensation, the Firm Performance, and the CEO Power. Thus, it concluded that the CEO Bonus model is not influenced by the sub-variables of the Firm Size - the Total Sales and the Total Employees; it concluded that the CEO Bonus model was not influenced by the sub-variables of the Firm Performance - the Return on Assets, the Return on Equity, the Earnings Per Share, the Cash Flow per Share, the Common Stock Outstanding, the Book Value of Common Stock, and the Market Value of Common Stock; and it concluded that the CEO Total Compensation model is not influenced by the sub-variables of the CEO Power - the CEO Age, the CEO Shares Outstanding, the CEO Share Values, the CEO Tenure, the CEO Turnover, the 5 percent Management Ownership, and the 5 percent Individuals/Institutions Ownership. 


\subsection{CEO Compensation and Firm Size}

Table 2: Correlations (CEO Compensation vs. Firm Size)

\begin{tabular}{|l|l|l|r|}
\hline & Salary & Bonus & Total Compensation \\
\hline Total Sales & 0.688 & -0.002 & 0.25 \\
\hline Total Employees & 0.423 & 0.015 & 0.356 \\
\hline
\end{tabular}

Table 2 illustrated the correlation results between the three categories of the CEO Compensation and the Firm Size. It showed that: there was a strong correlation existed between the CEO Salary, the Total Sales, and the Total Employees; there was a weak correlation existed between the CEO Bonus, the Total Sales, and the Total Employees, and there is a moderate relationship between the Total Compensation, the Total Sales, and the Total Employees. Thus, it signifies that, since Canadian financial institutions are mostly large and strong, the impact to the CEO Salary was strongly positively correlated. Interestingly, the Firm Size was not a factor in determining the CEO Bonus perhaps due to the importance of other factors such as organizational management and net profit margin. However, the Firm Size had a positive moderate relationship with the Total Compensation signifying that the non-cash compensation benefits had a moderate to good impact in determining the CEO compensation or the structure of the CEO compensation contract was designed more towards long-terms benefits.

\subsection{CEO Compensation and Firm Performance}

Table 3: Correlations (CEO Compensation vs. Firm Performance)

\begin{tabular}{|l|l|l|r|}
\hline & Salary & Bonus & Total Compensation \\
\hline Return on Assets & 0.011 & 0.151 & -0.076 \\
\hline Return on Equity & 0.168 & 0.252 & 0.093 \\
\hline Earnings Per Share & -0.1 & -0.079 & -0.023 \\
\hline Cash Flow Per Share & 0.06 & 0.054 & 0.044 \\
\hline Net Profit Margin & 0.686 & 0.116 & 0.298 \\
\hline Common Stock Outstanding & 0.506 & 0.014 & 0.183 \\
\hline Book Value of Common Stock & 0.603 & 0.06 & 0.309 \\
\hline Market Value of Common Stock & 0.658 & 0.11 & 0.246 \\
\hline
\end{tabular}

Table 3 results illustrated that the correlation between the three categories of the CEO Compensation and the Firm Performance. It showed that there was a weak 
positive correlation existed between the CEO Salary, the CEO Bonus, the CEO Total Compensation, the Return on Assets (ROA), the Return on Equity (ROE), and the Cash Flow Per Share (CFPS). Thus, it signifies that in the large Canadian financial institutions, among the balance sheets involved items such as ROA, ROE, and CFPS, the influence to any component of the CEO Compensation was characterized as weak positive, perhaps due to the CEO Compensation contract gives less importance to assets and related returns. On the other hand, there was a weak negative correlation existed between the CEO Salary, the CEO Bonus, the CEO Total Compensation, and the Earnings Per Share (EPS). Thus, it signifies that the shareholders earnings per share had nil to negative impact on the CEO Compensation. It was found that there was a strong correlation between the CEO Salary, the Net Profit Margin (NPM), the Common Shares Outstanding (CSO), the Book Value of Common Shares Outstanding (BVCSO), and the Market Value of Common Shares (MVCS). Thus, it signifies that the accounting net income is one of the major determinants of the CEO Salary. In addition, the Common Shares outstanding surprisingly found to be highly correlated with the CEO Salary this may perhaps related to the influence of additional shares issues to the employees especially to the management. In addition, the value of common shares both at cost and market were also found to be highly correlated with CEO Salary signifying the effect of strong earnings and positive market reactions.

\subsection{CEO Compensation and CEO Power}

Table 4: Correlations (CEO Compensation vs. CEO Power)

\begin{tabular}{|l|r|r|r|}
\hline & Salary & Bonus & Total Compensation \\
\hline CEO Age & 0.038 & 0.007 & 0.014 \\
\hline CEO Shares Outstanding & -0.185 & 0.007 & -0.101 \\
\hline CEO Share Value & -0.143 & 0.007 & -0.081 \\
\hline CEO Tenure & -0.165 & -0.232 & -0.203 \\
\hline CEO Turnover & -0.081 & 0.048 & -0.052 \\
\hline MGMT. 5\% Ownership & 0.255 & -0.13 & -0.098 \\
\hline INDV./INST. 5\% Ownership & -0.227 & 0.074 & -0.14 \\
\hline
\end{tabular}

The Table 4 results illustrated that the correlation between the three categories of the CEO Compensation and the CEO Power. It showed that there was a weak negative correlation existed between the CEO Salary, the CEO Age, the CEO Shares Outstanding, the CEO Share Value, the CEO Tenure, the CEO Turnover, the 5 percent Management Ownership, and the 5 percent Individuals/Institutions Ownership. Thus, it signifies that in the large Canadian financial institutions, these sub-variables of the CEO Power were a non-factor and in fact a negative impact in 
the determinant of the CEO Salary, except the 5 percent Management Shares Ownership which had a moderate correlation of .255. The correlations between the CEO Bonus, the CEO Age, the CEO Shares Outstanding, the CEO Share Value, the CEO Turnover, and the 5 percent Individuals/Institutions Ownership found to be weakly positive, except to the CEO Tenure and the 5 percent Management Ownership. Thus, it signifies that the sub-variables of the CEO Power had a weak influence on the bonus determination by the board. The one reason was perhaps due to Canadian financial institutions equity ownership and share price changes were insignificant, at least from the period 2005 to 2010. The other reason perhaps, the global credit crunch period from 2007 to 2009, although had a minimum impact on the strong Canadian financial institutions, yet may have some degree of impact towards this statistical results in a negative fashion. The correlations between the CEO Total Compensation, the CEO Shares Outstanding, the CEO Share Value, the CEO Tenure, the CEO Turnover, the 5 percent Management Ownership, and the 5 percent Individuals/Institutions Ownership found to be weakly negative, except to the CEO Age weak positive ratio. Thus, it signifies that the CEO Total Compensation which includes the non-cash components, found to have nil to negative influence by the sub-variables of the CEO Power. More importantly, overall, the CEO Power had no influence on the CEO Compensation, this is perhaps true in light of the ownership structure in the Canadian financial institutions, that is, the Canadian financial institutions shares are mostly owned (less than 5 percent) by the individuals or institutions. In addition, the Canadian financial institutions securities laws such as: Office of the Superintendent of Financial Institutions Act; Bank Act; Trust and Loan Companies Act; Cooperative Credit Associations Act; and Insurance Companies Act, prohibited any form of the management ownership, or prohibited any individuals or institutions owning significant ownership to create monopoly individually or as a group.

\section{Conclusion ${ }^{3}$}

Overall, there was a relationship between the CEO Salary, the Firm Size, the Firm Performance and the CEO Power; there is a relationship between the CEO Bonus, the Firm Performance, and the CEO Power; there was a relationship between the CEO Total Compensation, the Firm Size, and the Firm Performance. However, there was no relationship found: between the CEO Bonus, the Firm Size, and the Firm

\footnotetext{
${ }^{3}$ Further Study: Although this study of the Canadian Financial Institutions CEO Compensation System was comprehensive in nature by attesting the CEO Compensation with relevant variables such as the Firm Size, the Firm Performance, and the CEO Power, however, qualitative areas such as the effect of the board composition to the CEO Compensation in the Canadian Financial Institutions; the effect of the non-monopolized ownership structure in the Canadian Financial Institutions on the CEO Compensation, and the effect of the Canadian government regulations on financial institutions on CEO Compensation, all would greatly assist in understanding the additional dynamics of the Canadian Financial Institutions CEO Compensation system.
} 
Performance; and between the CEO Total Compensation and the CEO Power. The correlation between the CEO Salary, the Total Sales, and the Total Employees was strong, however, the correlation between the CEO Bonus, the Total Sales, and the Total Employees was weak, and however, the correlation between the CEO Total Compensation, the Total Sales, and the Total Employees was moderate.

There was a weak positive correlation existed between the CEO Salary, the CEO Bonus, the CEO Total Compensation, the Return on Assets (ROA), the Return on Equity (ROE), and the Cash Flow Per Share (CFPS). However, there was a weak negative correlation existed between the CEO Salary, the CEO Bonus, the CEO Total Compensation, and the Earnings Per Share (EPS). However, there was a strong correlation existed between the CEO Salary, the Net Profit Margin (NPM), the Common Shares Outstanding (CSO), the Book Value of Common Shares Outstanding (BVCSO), and the Market Value of Common Shares (MVCS). However, there is a weak to moderate positive relationship between the CEO Bonus, the CEO Total Compensation, the NPM, the CSO, the BVCSO, and the MVCSO.

There was a weak negative correlation existed between the CEO Salary, the CEO Age, the CEO Shares Outstanding, the CEO Share Value, the CEO Tenure, the CEO Turnover, the 5 percent Management Ownership, and the 5 percent Individuals/Institutions Ownership. The correlations between the CEO Bonus, the CEO Age, the CEO Shares Outstanding, the CEO Share Value, the CEO Turnover, and the 5 percent Individuals/Institutions Ownership found to be weakly positive, except to the CEO Tenure and the 5 percent Management Ownership. The correlations between the CEO Total Compensation, the CEO Shares Outstanding, the CEO Share Value, the CEO Tenure, the CEO Turnover, the 5 percent Management Ownership, and the 5 percent Individuals/Institutions Ownership found to be weakly negative, except to the CEO Age weak positive ratio.

\section{References}

Agrawal, A. and Knoeber, C.R. (1996), 'Firm performance and mechanisms to control agency problems between managers and shareholders', Journal of Finance Quantitative Analysis, Vol. 31(3), pp. 377-397.

Allen, M.P. (1974), 'The Structure of inter-organizational elite co-optation', American Sociological Review, Vol. 39, pp. 393-406.

Amould, R.J. (1985), 'Agency costs in Banking Firms: An Analysis of Expense Preference Behaviour', Journal of Economics and Business, Vol. 37, pp. 103-112.

Antle, R. and Smith, A. (1986), "An Empirical Investigation of the Relative Performance Evaluation of Corporate Executives", Journal of Accounting Research, Vol. 24, No. 1, Spring, pp. 1-39. 
Belkaoui, A. and Picur, R. (1993), “An analysis of the use of accounting and market measures of performance, CEO experience and nature of deviation from analyst forecasts", Managerial Finance, Vol. 19(2), pp. 33-54.

Bertrand, M. and Mullainathan, S. (2001), "Are CEO's Rewarded for Luck? The Ones Without Principals Are", Quarterly Journal of Economics, pp. 901-932.

Blanchard, O.J., Lopez-de-Selanes, F. and Shleifer, A. (1994), "What do Firms do with Cash indfalls?", Journal of Financial Economics, Vol. 36 (3), pp. 337-360.

Borman, W.C. and S.J. Motowidlo (1993), "Expanding the criterion domain to include elements of contextual performance", in Schmitt, N. \& Borman, W.C. (Eds.), Personnel selection in organizations, pp. 71-98, Jossey Bass, San Francisco, CA.

Boyd, B.K. (1994), "Board Control and CEO Compensation", Strategic Management Journal, Vol. 15, pp. 335-344.

Carpenter, M.A. and Sanders, W.M. (2002), “Top management team compensation: The missing link between CEO pay and firm performance", Strategic Management Journal, 23, pp. 367-375.

Coughan, A.T. and Schmidt, R.M. (1985), "Executive Compensation, Management Turnover, and Firm Performance: an Empirical Investigation”, Journal of Accounting and Economics, Vol. 7, Nos. 1-3 (April), pp. 43-66.

Cyert, R., K. Sok-Hyon and Kumar, P. (2002), "Corporate Governance, Take-overs, and Top-Management Compensation: Theory and Evidence", Management Science, Vol. 48 (4), pp. 453-469.

David, P., Kochar, R. and Levitas, E. (1998), "The effect of institutional investors on the level and mix of CEO compensation", Academy of Managerial Journal, Vol. 41, pp. 200-228.

Deckop, J.R. (1988), "Determinants of Chief Executive Officer Compensation”, Industrial and Labor Relations Review, Vol. 41, No. 2, pp. 215-226.

Demsetz, H. and Villalonga, B. (2001), "Ownership structure and corporate performance", Journal of Corporate Finance, Vol. 7(3), pp. 209-233.

Dyl, E.A. (1998), "Corporate control and management compensation", Managerial and Decision Economics, Vol. 9, pp. 21-25.

Finkelstein, S. and Boyd, B.K. (1998), "How much does CEO matter? The role of managerial discretion in the setting of CEO compensation", Academy of Management Journal, Vol. 41, pp. 179-199.

Finkelstein, S. and Hambrick, D. (1989), "Chief executive compensation: A Study of the intersection of markets and political processes", Strategic Management Journal, Vol. 10, Issue 2, pp. 121-134.

Finkelstein, S. and Hambrick, D. (1996), Strategic Leadership: Top Executive and their Effects on Organization, West Publishing, New York.

Fox, H. (1983), Top Executive Compensation, Conference Board Publication.

Gibbons, R. and Murphy, K.J. (1990), "Relative Performance Evaluation for Chief Executive Officers", Industrial and Labor Relations Review, Vol. 43, No. 3, pp. 30S-51S.

Gomez-Mejia, L.R., Tosi, H.L. and Hinkin, T. (1987), "Managerial control, performance, and executive compensation", Academy of Management Journal, Vol. 30, pp. 51-70.

Gomez-Mejia, L.R. and Barkema, H.G. (1998), "Managerial Compensation and Firm Performance: A General Research Framework" The Academy of Management Journal, Vol. 2, No. 2, Special Research Forum on Managerial Compensation and Firm Performance, pp. 135-145. 
Gomez-Mejia, L.R. and Tosi, H.L. (1989), “The Decoupling of CEO Pay and Performance: An Agency Theory Perspective", Administrative Science Quarterly, 34, pp. 169-189.

Gomez-Mejia, L.R. and Tosi, H.L. (1994), "CEO Compensation Monitoring and Firm Performance", The Academy of Management Journal, Vol. 37, No. 4. August, pp. 10021016.

Gray, S.R. and Cannella, A.A. (1997), "The Role of Risk in Executive Compensation", Journal of Management, Vol. 23, pp. 517-540.

Hambrick, D.C. and Finkelstein, S. (1995), "The Effects of Ownership Structure on Conditions at the Top: The Case of CEO Pay Raises", Strategic Management Journal, Vol. 16, pp. 175-194.

Himmelberg, C.P, Hubbard, R.G. and Palia, D. (1999), "Understanding the determinants of managerial ownership and the link between ownership and performance", Journal of Finance Economics, Vol. 53(3), pp. 353-384.

Iyengar, R.J. (2000), “CEO Compensation In Poorly Performing Firms”, Journal of Applied Business Research, Vol. 16, Issue 3, pp. 1-28.

Jensen, M. and Murphy, K. (1985), "Management Compensation And The Managerial Labor Market", Journal of Accounting and Economics, Vol. 7, No. 1-3, pp. 3-9.

Jensen, M. and Murphy, K. (1990), "Performance pay and top management incentives", Journal of Political Economy, Vol. 98, pp. 225-264.

Jensen, M. and Murphy, K. (1990b), "CEO Incentives: It's not how much you pay but how", Harvard Business Review, Vol. 68, No. 3, pp. 138-153.

Jensen, M. and Murphy K., (2010), "CEO incentives - It's not how much pay, but how", Journal of Applied Corporate Finance, Vol. 22, pp. 64-76.

Jensen, M.C. and Meckling, W.H. (1976), "Theory of the firm: Managerial behaviour, agency costs and ownership structure", Journal of Financial Economics, Vol. 3, pp. 305-360.

Jensen, M.C. and Ruback, R.S. (1983), "The market for corporate control”, Journal of Financial Economics, Vol. 11, pp. 5-50.

Jensen, M.C. and Zimmerman, J.L. (1985), "Management Compensation and The Managerial Labour Market", Journal of Accounting and Economics, Vol. 7, No. 1-3, pp. 3-9.

Joskow, P.L. and Nancy, L. (1994) "CEO Pay and Firm Performance: Dynamics, Asymmetries, and Alternative Performance Measures", NBER Working Paper Series, Vol. W, pp. 4976.

Kostiuk, P.F. (1990), "Firm Size and Executive Compensation", The Journal of Human Resources, University of Wisconsin Press, Vol. 25, pp. 90-105.

Lambert, R. and Larker, D. (1984), "Stock Options and Marginal Incentives", Working Paper, Northwestern University, Evanston, IL.

McEachern, W. (1975), "Managerial control and performance", Lexington Books, Lexington, MA.

Mehran, H. (1992), "Executive Incentive Plans, Corporate Control, and Capital Structure", Journal of Financial and Quantitative Analysis, Col. 27, pp. 539-560.

Mehran, H. (1995), "Executive compensation structure, ownership, and firm performance" Journal of Financial Economics, Vol. 38, pp. 163-184.

Murphy, K.J. (1985), "Corporate performance and managerial remuneration", Journal of Accounting and Statistics, Vol. 7, pp. 11-42. 
Murphy, K.J. (1986), "Incentives, learning and compensation: A theoretical and empirical investigation of managerial labor contracts", Rand Journal of Economics, Vol. 7, pp. 105-131.

Murphy, K.J. (1999), “Executive Compensation', Handbook of Labor Economics”, Vol. III, North-Holland, Amsterdam, pp. 2485-2563.

Murphy K.J. and Gibbons, R. (1989), Optimal Incentive Contracts in the Presence of Career Concerns: Theory and Evidence, pp. 90-109.

Murphy, K.J. and Oyer P., (2002), Discretion in executive incentive contracts: Theory and evidence, Working paper, University of Southern California and Stanford University.

Murphy, K.R. and Slater, M. (1975), "Should CEO pay be linked to results?", Harvard Business Review, Vol. 53(3), pp. 66-73.

Pfeffer, J. (1981), Managing with Power, Pitman Publication, London.

Prasad, S.B. (1974), "Top Management Compensation and Corporate Performance" The Academy of Management Journal, Vol. 17, pp. 554-558.

Sigler, K.J. (2011), "CEO Compensation and Company Performance", Business and Economic Journal, Vol. 2011, pp. 1-8.

Sanders, W.G. and Carpenter, M.A. (1998) "Internationalization and firm governance: The roles of CEO compensation, top team composition, and board structure", Academy of Management Journal, Vol. 41, pp. 158-178.

Sigler, K.J. (2011), "CEO Compensation and Company Performance", Business and Economic Journal, Volume 2011, pp. 1-8.

Simmons, S.A., Kroll, M. and Wright, P. (1991), Winners and Losers in Acquisitions: A Canonical Correlation Analysis, Southeastern Division of The Institute of Management Sciences Meeting.

Sloan, R. (1993), “Accounting Earnings and Top Executive Compensation", Journal of Accounting and Economics, Vol. 16, pp. 55-100.

Thalassinos, I.E., Havlíček, K. and Berezkinova, L. (2012), "Innovation Management and Controlling in SMEs", European Research Studies Journal, Vol. XV, Special Issue, pp. 110-123.

Tosi, H.L., Werner, S., Katz, J. and Gomeiz-Mejia, L.R. (1998), A Meta-Analysis of Executive Compensation Studies, Unpublished Manuscript, University of Florida at Gainesville.

Tosi, H.L., Werner, S. Katz, J. and Gomeiz-Mejia, L.R. (2000), "How Much Does Performance Matter? A Meta-Analysis of CEO Pay Studies", Journal of Management, Vol. 26, pp. 301-339.

Ungson, G.R. and Richard, S.M. (1984), "Motivation and politics in executive compensation", Academy of Management Review, Vol. 9, pp. 313-323.

Werner, S. and Tosi, H.L. (1995) "Other People's Money: The Effect of Ownership on Compensation Strategy and Managerial Pay", Academy of Management Journal, Vol. 38, pp. 1672-1691.

Zampeta, V. (2012), "How Corporate Governance and Globalization Affect the Administrative Structure of the Greek Shipping Industry", Journal of Global Business and Technology, Vol. 8, No 2, pp. 48-58. 